\title{
Impact of service Environment and Service Quality on Customer Satisfaction and Behavioral Intentions in Hotels
}

\author{
Yasser Ibrahim* \\ Abu Elnasr Sobaih* \\ Mahmoud El-Sayiad* \\ *Faculty of Tourism and Hotel Management, Hewlan University
}

\begin{abstract}
The purpose of this study is to propose an integrated model that examines the impact of service environment (servicescape) and service quality on customer satisfaction and behavioral intentions in hotels. Data was collected from guests of three upscale hotels in the region of Virginia, USA via self-administered survey. Anderson and Gerbing's two-step approach was used to assess the measurement and structural models. Structural equation modeling revealed that servicescape affects customer satisfaction, service quality and customer behavioral intentions positively; it was also found that, quality of services offered in luxury hotels leads to customer satisfaction and interestingly, results showed that service quality does not influence customers' behavioral intentions. Furthermore, Customer satisfaction was found to positively affect customers' behavioral intentions in hotels. On the other hand, the findings confirm that service quality, customer satisfaction had a mediating effect on the relationship between servicescape and behavioral intentions. The study findings will significantly help researchers and practitioners understand the complex relationships among service environment, service quality, customer satisfaction and behavioral intentions in the hotel industry.
\end{abstract}

Keywords: Service Environment, Service Quality, Customer satisfaction, behavioral Intentions.

\section{Introduction}

As service providers find it increasingly difficult to create a differential advantage in service delivery, the service environment itself becomes a fertile opportunity for market differentiation (Lee, 2011). In this context of increasing competition, service firms must be certain that their service environments appeal to customers Mattila and Enz (2002). As services are produced and consumed simultaneously, customer affective responses to various cues within service environments have a strong impact on perceptions and behavior (Chang, 2000; Baker et al., 2002; Tsai and Huang, 2002). Pleasure derived from the service environment influences in-store behaviors such as amount of time spent in the store, spending levels and willingness to revisit (Donovan and Rossiter, 1982; Donovan et al., 1994; Yoo et al., 1998). Therefore, service organizations have a strategic stake in understanding how service environments reinforce customers' satisfaction and behavioral intentions (Sherman et al., 1997).

The main purpose of the study is to examine the relationship between servicescape, service quality, customer satisfaction and behavioral intentions within the framework of hotel business. 
Most studies that have examined servicescape perceptions of customers have been done on restaurants (Kim and Moon, 2009; Han and Ryu, 2009; Liu and Jang, 2009; Jang and Namkung, 2009; Lin and Mattila, 2010; Heung and Gu, 2012; Voon et al., 2013; Wang and Mattila, 2013; Hyun and Kang, 2014). However, it can be argued that as hotel businesses play a central role in the tourism sector (Pike and Ryan, 2004) and where customers spend quite a lot of time (Wakefield and Blodgett, 1999), not sufficiently investigating the aforementioned relationships in terms of hotel businesses points to a deficiency in the research. Thus, investigating servicescape, service quality, customer satisfaction and behavioral intentions within the framework of hotel businesses contributes to the literature, would be of value to the field and bridge this gap. In addition, this study hopes to create an awareness of the importance of servicescape in the hotel sector.

Customers in the hotel industry are mostly in contact with the physical environment rather than personnel services (Kim and Moon, 2009). In fact, customers interact with the physical elements before experiencing the service. Lin (2004) stated that the moment a tourist first enters a hotel, their initial contact is with the physical environment rather than with personnel. He added that considering all these factors it can be said that servicescape is very effective in the general evaluation of a service organization. Moreover, considering that customers spend more time in hotels compared to other service organizations, it can be said that their interaction with servicescape lasts for a long period of time. The servicescape of the hotel should be arranged in a way that makes a customer feel that the expense and time expended on the trip was worth it. Therefore, hotel businesses should pay attention to each detail rather than ignore servicescape arrangement (e.g. running air conditioners too hot or too cold, inappropriate furnishings, signs that are not sufficiently informative) and only focus on short-term benefits. When a tourist arrives after a long journey and enters a hot lobby, hotel personnel's' high performance and friendly manner is not sufficient.

While dense researches have been carried out on servicescape in restaurants (Liu and Jang, 2009, Kim and Moon, 2009, Jang and Namkung, 2009, Han and Ryu, 2009, Lin and Mattila, 2010, Heung and Gu, 2012). More theoretical and empirical studies are needed in this field (Mari and Poggesi, 2013). Moreover, very few studies conducted on servicescape in the context of hotels (Dedeoğlu et al., 2015). Therefore, this study bridges this gap by emphasizing the impact of servicescape and service quality on customer satisfaction and behavioral intentions in hotels.

\section{Literature Review}

\section{Servicescape}

Servicescape is defined as a combination of several dimensions that influence customers' holistic perceptions of the service and it describes the manmade physical surroundings (as opposed to the natural or social environment) that affect customer perceptions of service and may lead to (or away from) customer satisfaction (Bitner, 1992). 
It is largely described as the effect of atmospherics, décor, facility design, and layout on a customer's perception of quality, that customer' $s$ current and future buying behaviors, and his or her perceptions of the firm. The dimensions of servicescape generally described in the literature are ambient conditions, spatial layout and functionality, and signs/symbols and artifacts. Research suggests it has particular relevance in the service industry due to the intangible and relatively short-term nature of services (Parasuraman et al., 1988; Bitner et al., 1990; Bitner, 1992; Zeithaml et al., 1993).

Unlike manufactured goods, services are generally produced and consumed simultaneously, most often while the customer is present in the service delivery system. Customer perceptions about servicescape have been shown to stimulate emotional responses about firm image and purpose, and these perceptions have also been shown as significant influences on the accomplishment of organizational goals and marketing objectives (Bitner et al., 1990). As a result, servicescape is an important for service firms.

\section{Dimensions of Servicescape}

Physical environment has been classified differently in previous studies. Bitner (1992) classified servicescape as ambient conditions, spatial layout and functionality, and signs, symbols, and artefacts. Han and Ryu (2009) focused on décor and artifacts, spatial layout, and ambient conditions in order to examine the factors of physical environment within a restaurant context. Wakefield and Blodgett (1996), whose study was conducted within the leisure services, stated that built environment can be controlled, therefore they focused on layout accessibility, facility aesthetics, seating comfort, electronic equipment/displays, and facility cleanliness, and did not focus on ambient conditions.

Heung and $\mathrm{Gu}$ (2012) in their study of influence of atmospherics on patron satisfaction and behavioral intentions in restaurants focused on ambient conditions, facility aesthetics and spatial layout and employee. Nguyen and Leblanc (2002) divided physical environment into five items: ambient conditions, exterior layout, interior layout, décor, and location within an insurance services and hotel services context. Shashikala and Suresh (2013) examined the effect of servicescape in shopping centers on customer loyalty and indicated that servicescape is composed of seven components: ambient factor; aesthetic factor; layout; variety; cleanliness; signs, symbols, and artifacts; and social factors.

Hooper et al. (2013) stated that servicescape is composed of equipment, design, space, ambience, and hygiene, and considered it to be one of the antecedent components of service quality. Additionally, in different studies, servicescape has been examined in the context of the physical factor, which is one of the components of service quality (Reimer and Kuehn, 2005; Sureshchandar et al., 2002; Sureshchandar et al., 2001).

According to Kim and Moon (2009) and Namasivayam and Lin (2008), the elements of servicescape have to be examined according to their different 
contexts. In this research, servicescape in hotel management is explained in the context of ambience, layout, décor, and signs, which, as Dong and Siu (2013) point out, are explained as substantive staging of servicescape. It must be emphasized that in this study the research focused on functional and mechanical elements; the communicative staging of servicescape (its human clues) was not included. The study was also limited to the interior environment of a hotel. As customers spend much more time in hotels than in restaurants. Therefore, the effect of servicescape on the perception of hotel customers may be more significant (Wakefield and Blodgett, 1999). Although the effect of servicescape components can be examined separately (Harris and Ezeh, 2008), servicescape, as Bitner (1992) stated, includes a number of components, such as ambiance, spatial layout, signs, and so on. Consequently, in this paper studying a number of components as a whole was found to be more useful than examining the effects of servicescape components separately. Authors undertaking similar studies have also found this to be the case (Kim and Moon, 2009; Hooper et al., 2013).

The concept of ambience, which forms the physical environment, includes music, smells, lighting, and heating (Han and Ryu, 2009; Heung and Gu, 2012; Lucas, 2003). Layout is a concept related to the positioning of the furniture and various equipment in areas used by customers in ways that enable comfortable movement in general usage areas. It also takes into account how general usage areas can be reached (Han \& Ryu, 2009; Heung and Gu, 2012; Turley and Milliman, 2000). The concept of decor is related to the color of the floors and walls, and the quality of the materials (Han and Ryu, 2009). Finally, signs are used as both explanatory directives (name of the organization), for example, pointing to the location of the restaurant, and as informative elements (as in "no smoking" signs) (Bitner, 1992; Kim and Moon, 2009). The importance of the signs is better understood when considering that any number of people are present in the hotel simultaneously.

\section{Servicescape and behavioral intentions}

Over the past three decades, numerous studies have been carried out to investigate the influence of atmospherics on customers' behavioral intentions in the service context including retail and food service settings. Tai and Fung (1997) distinguished two mainstreams of literature on atmospherics in service settings, and recent studies generally fall into one of these two streams. On the one hand are studies that take a comprehensive approach, focusing on the combined effects of various elements of the atmosphere on consumer behavior (Chang, 2000; Donovan and Rossiter, 1982; Liu and Jang, 2009; Ryu and Han, 2010; Ryu and Jang, 2007; Wakefield and Blodgett, 1996). On the other hand are studies that focused on specific atmospheric elements, including crowding (Yildirimand Akalin-Baskaya, 2007), store window type (Yildirim et al.,2007), lighting (Areni and Kim, 1994; Summers and Hebert, 2001),aroma (Gueguen and Petr, 2006; Gulas and Bloch, 1995), and music (Caldwell and Hibbert, 1999; Jacob, 2006; Milliman, 1986; North and Hargreaves, 1996; Wilson, 2003), or paired elements (e.g., scent and music) (Mattila and Wirtz, 
2001; Morrison et al., 2011). In the present study, a comprehensive approach was adopted to measure the combined effects of hotel's atmospherics on customers' behavior.

Of those studies that treat atmospherics as a holistic concept, the majority have found customer behavior to be influenced by atmospherics in an indirect way, i.e., it is usually claimed that the effects are mediated by other variables. For instance, Liu and Jang (2009) advanced the notion that the influence of restaurant atmospherics on behavioral intentions is mediated by emotions and perceived value. Chang (2000) and Wakefield and Blodgett (1996) found the physical environment to have no significant direct effect on return intentions; rather, its effect was found to be mediated through customer satisfaction. East (1997), however, proposed that the service environment's effects on consumer behavior are not necessarily mediated by emotional states or satisfaction level. Dube, et al. (1994) and Soriano (2002) suggested that atmosphere/ambience has a significant impact on return patronage. It may be that the service atmosphere directly stimulates behavior. Ibrahim (2009), also found in his study of servicescape in coffee shops a positive strong effect of serviceescape elements on customers' behavioral intentions. This debate leads us to this study's first hypothesis, which is as follows:

H1: Hotel Servicescape has a positive influence on customers' behavioral intentions

\section{Servicescape and customer satisfaction}

Bitner (1992) and Wakefield and Blodgett (1994, 1996, 1999) suggested that the servicescape has a significant effect on customer satisfaction in the leisure context. In particular, Wakefield and Blodgett (1994) argued that the longer the time that customers need to spend inside a business facility when the service provided is a leisure service, the more important the role of the environment in affecting customer satisfaction. Francoeur (1992) suggested that cleanliness, interior décor, and overall lighting levels are important attributes of a desirable physical environment. Lucas (2003) argued that in the casino context, ambient factors, layout navigation, cleanliness, interior décor, and seating comfort are the major components determining satisfaction with the servicescape.

Lam, et al. (2011), in their study of servicescape, customer satisfaction, intention to revisit and desire to stay in Casinos, found that servicescape in casinos significantly affects customer satisfaction Ladhrari et al. (2008) added that customer satisfaction with restaurant service is determined by the quality of the food (the functional outcome), the cost/value of the meal, and the manner in which service is delivered. Atmospherics belongs to the third category. Moreover, Ryu and Han (2010), stated that atmospherics may, to a large extent, determine the overall degree of such satisfaction in the restaurant industry, taking into account the intangible nature of service processes.

Unconsciously perceived background music, color schemes, and the light could become the prime determinants of post-consumption satisfaction in a situation with no disconfirmation (the discrepancy between expectation and 
performance), which is the usual consumption experience (Wirtz and Bateson, 1999). Research also supports the link between atmospherics and customer satisfaction. For instance, Wakefield and Blodgett (1996) examined the effects of layout accessibility, facility aesthetics, electronic equipment, seating comfort, and cleanliness on the perceived quality of the servicescape, and found that the perceived quality of the physical environment significantly affects customer satisfaction in the leisure service setting. Moreover, Chang (2000), in an investigation of the impacts of the physical environment on customer satisfaction in college sports arenas, confirmed the direct and positive relationship between the two. Jana and Chatterjee (2014) studies the effects of servicescape on youth dining experience in restaurants and found that there is positive relation between layout and ambience on customer satisfaction, Therefore, we hypothesize the following:

H2: Hotel servicescape has a positive influence on customer satisfaction.

\section{Servicescape and service quality}

Although numerous articles emphasize the importance of the servicescape, the effect of the servicescape on quality perception has been inadequately captured by previous empirical research. Reimer and Kuehn (2005) studied the effect of servicescape on service quality in retail banking, for utilitarian reasons and in restaurants as well, for hedonic reasons and interestingly they found that servicescape has higher significance on service quality than was supposed in most previous studies in both utilitarian and hedonic settings. Moreover, Hightower et al., (2002), found a strong positive relationship between servicescape and service quality in hedonic service consumption. Reimer and Kuehn (2005) agreed with previous authors that servicescape has a direct influence on service quality. Hence, we hypothesize the following:

H3: Servicescape affects service quality positively.

\section{Influence of service quality on satisfaction.}

There have been mixed findings about the causal direction between service quality and customer satisfaction. The most common explanation for the difference is that perceived service quality is described as a form of attitude, a long-run overall evaluation of a product or service, whereas satisfaction is a transaction-specific evaluation (Bitner,1990; Cronin and Taylor, 1992; Oliver, 1981; Parasuraman et al.,1988). Based on these conceptualizations, incidents of satisfaction over time lead to perceptions of service quality. For instance, Bitner (1990) developed a model of service encounter evaluation and empirically showed that satisfaction was an antecedent of service quality.

In contrast, many other researchers empirically supported the influence of perceived service quality on customer satisfaction (Cronin and Taylor, 1992; Spreg and MacKoy, 1996; Ting, 2004).

For instance, Cronin and Taylor (1992) examined the conceptualization and measurement of service quality and the relationships among service quality, consumer satisfaction, and purchase intentions. The findings suggested that 
service quality was an antecedent of consumer satisfaction whereas consumer satisfaction was not a significant predictor of service quality. Spreg and MacKoy (1996) also discussed the conceptual arguments behind the distinction, and investigated the relationship between service quality and satisfaction by testing a modified Oliver's (1993) satisfaction/service quality model. The results indicated that their modified model fit the data well when perceived service quality was an antecedent of satisfaction.

Moreover, Lee et al., (2000) examined the direction of causality between service quality and satisfaction. The findings showed that perceived service quality was an antecedent of satisfaction, rather than vice versa. Consistent with these findings, Ting (2004) suggested that service quality better explains customer satisfaction, and the coefficient of the path from service quality to customer satisfaction is greater than the coefficient of the path from customer satisfaction to service quality in the service industry. With regard to the lack of consensus, Parasuraman et al. (1994) posited that "the conflicting perspectives could be owing to the global judgment focus in most service quality research in contrast to the transaction-specific focus in most satisfaction research" (p. 111). They suggested that perceived service quality and customer satisfaction could be investigated from both transaction-specific and global perspectives. Thus, we propose here that customers can evaluate (be satisfied/dissatisfied with) an object or service only after they perceive the object or service. More specifically, we propose that customers may perceive the service quality immediately after service experience as well as at a later time and compare their perceptions with their expectations. The perceived service quality, expectations, and disconfirmation lead to satisfaction/dissatisfaction, Oliver and swan (1989). Therefore, it can be hypothesized that

H4: Quality of service has a positive influence on customer satisfaction.

\section{Service quality and behavioral Intentions}

The relevance of quality for the success of a hotel cannot be ignored, due to the relationship it has with satisfaction and repeated buyer behavior and positive word-of-mouth. Getty and Thompson (1995) demonstrated that recommendation intentions are more affected by the general quality provided by a service than by the expressed level of satisfaction. The specific dimensions of service quality that influence the intention to recommend are the external appearance of the hotel, the perceived value associated with the stay, the willingness of employees to listen to consumers and the safety environment of the property.

A Study conducted by Barksy and Labagh (1992) in the hospitality sector, found a positive relationship between some service qualities dimensions that lead to satisfaction and the intention of returning. Also in the tourism sector, Gonzales et al. (2007) demonstrated the influence of service quality on behavioral intentions.

Salazar et al. (2010) agreed with previous researchers, as they found a strong relationship between service quality and behavioral intentions like intention to recommend and intention to return to the hotel. A study in the electronic 
shopping, confirmed with previous studies that there is a strong relation between service quality and behavioral intentions Gounaris et al. (2010). Amin and Nasharuddin (2013) in their study of hospital service quality, found that service quality in hospitals impact patient's behavioral intentions, like willingness to recommend the hospital to others, willingness to inform about the advantages of the hospital and considering the same hospital as a first choice in future medical treatment. Moreover, Jang and Namkung (2008) in their findings, they agreed with all previous authors that there is a strong positive relationship between service quality and behavioral intentions. based on all this work, we can hypothesize that:

H5: Service Quality has a positive impact on customers' behavioral Intentions in hotels.

\section{Influence of customer satisfaction on behavioral intention.}

Customer satisfaction is very important, as it can directly affect organizational profits, customer loyalty, complaint behavior, return patronage and word-ofmouth (WOM) behavior (Dube et al., 1994; Ladhrari et al., 2008; Soriano, 2002). Numerous researchers have verified the significant relationship between customer satisfaction and behavioral intention in business and hospitality fields. Getty and Thompson (1995) examined the roles of service quality and satisfaction in explaining behavioral intention. Their findings indicated that high level of satisfaction increases customers' intentions to repurchase and recommend the product. In their investigation of guest behaviors in the lodging industry, Han and Back (2008) explained the formation of revisit intention. The results of their study showed that guests' intention to revisit is a positive function of satisfaction. In an upscale restaurant setting, Han and Ryu (2007) found that improving customer satisfaction level is essential to increase revisit and recommendation intentions. Dissatisfied customers are likely to switch, complain, or spread negative word of mouth (Oliver, 1997). The obvious need for satisfying customers is to acquire repeat business and positive word of mouth, thereby improving profit Barsky and Richard (1992). Lucas (2003) and Kim and Moon (2009) found from studies conducted in a leisure context that customers tend to revisit when they are satisfied with the environment. However, when customers experience anger and dissatisfaction, negative behavioral responses such as switching to another service provider may occur.

Lam et al. (2011), in their study of servicescape, customer satisfaction, intention to revisit and desire to stay in Casinos, found that customers' level of satisfaction affects their intention to revisit the same casino. Studies have demonstrated the direct relationship between satisfaction and behavioral intentions to revisit and recommend to others (Chen and Chen, 2010), as well as willingness to pay more (Lee et al., 2010).

Customer satisfaction can positively influence purchase volume and loyalty (Cronin et al., 2000) and repurchase intentions (Rust and Williams, 1994). Lee et al. (2010) found that satisfaction with a hotel's overall image can contribute to more favorable behavioral intentions such as positive word of mouth, 
willingness to pay a premium and intention to revisit. A happy customer is less likely to spread negative word-of-mouth (Szymanski and Henard, 2001) or to search for information on alternatives and resist close relationships with the service provider (Anderson and Srinivasan, 2003).

Han et al. (2009) investigated the relationship among consumption emotions, customer satisfaction, switching barriers, and the revisit intention in the restaurant business. Their findings indicate that guests' intention to revisit is a positive function of satisfaction. Oh (2000) also found satisfaction to be a powerful predictor of customer repurchase and referral intentions. However, some research has suggested that the link between customer satisfaction and future intentions is weak. For example, in comprehensive research on the determinants of dining satisfaction and return patronage, Kivela et al. (1999, 2000) concluded that satisfied customers are not necessarily loyal customers. Return patronage is instead the result of the interplay among several factors. Furthermore, a study carried out by Chow et al. (2007) reported a nonsignificant link between satisfaction and repeat patronage. These heterogeneous arguments prompted the development of the fifth and final hypothesis of this study.

H6: Customer satisfaction has a significant direct effect on behavioral intention.

\section{Conceptual Background}

Numerous studies have investigated the influence of atmospherics on customers' behavioral intentions in the service context including retail and food service settings. The majority have found customer behavior to be influenced by atmospherics in an indirect way, i.e., it is usually claimed that the effects are mediated by other variables. For instance, Chang (2000) and Wakefield and Blodgett (1996) found the physical environment to have no significant direct effect on return intentions; rather, its effect was found to be mediated through customer satisfaction. East (1997) and Hooper, Coughlan and Mullen (2013), however, proposed that the service environment's effects on consumer behavioral intentions are not necessarily mediated by emotional states or satisfaction level. Dube, et al. (1994) and Soriano (2002) suggested that atmosphere/ambience has a significant impact on return patronage. It may be that the service atmosphere directly stimulates behavior. Ibrahim (2009), also found in his study of servicescape in coffee shops a strong positive effect of serviceescape elements on customers' behavioral intentions.

Hooper et al. (2013) asserted that servicescape is a separate construct which precedes service quality, Hightower et al. (2002), found a strong positive relationship between servicescape and service quality in hedonic service consumption.

Reimer and Kuehn (2005) agreed with previous authors that servicescape has a direct influence on service quality. Service quality was mediated between servicescape customer satisfaction and behavioral intentions in multiple researches (Hooper et al. 2013; Lee, 2014; Change, 2016). 


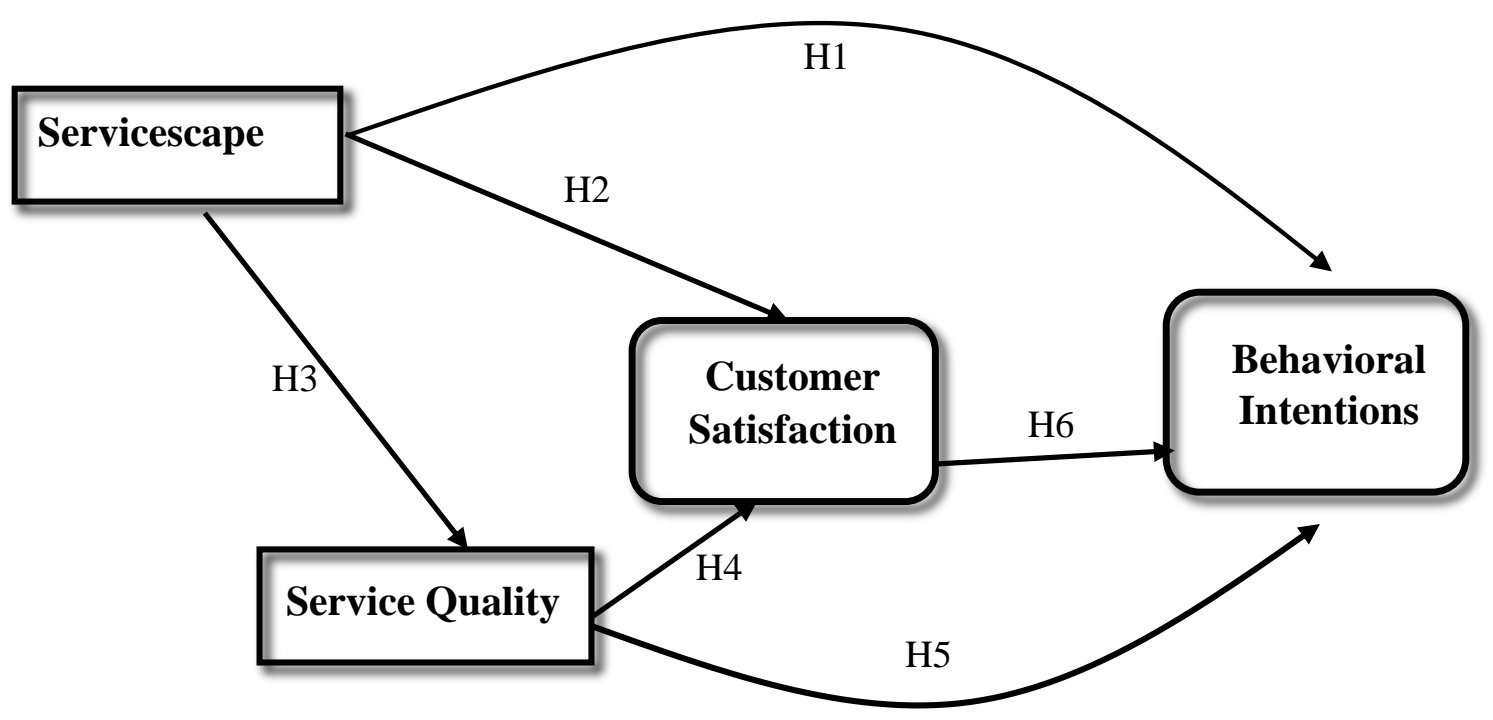

Figure1: Research conceptual framework; servicescape, service quality, customer satisfaction and behavioral intentions

\section{Research Methodology}

\section{Sample and Data Collection}

The participants in this study were upscale hotels' guests, 420 survey forms were handed to hotel guests face to face in the region of Virginia, USA (Residence Inn Arlington Capital view, Ritz Carlton Tysons Corner and Sheraton Pentagon City), it took six weeks to finish the distribution and 396 forms were valid. Among the sample \%49.3 were males, \%50.7 were females, the majority of respondents were single \%35.5, and most of them were between the age of 26 to 35 (\%33). About \%38.9 of respondents had college or University degree, followed by high school or below degree (\% 31.5) and about $\% 29.6$ had a post graduate degree.

\section{Research Instrument}

The Questionnaire used in the research consisted of five parts. The first part included questions about the service environment and was divided into two sub-sections asked customers about their room service environment and about hotel public spaces service environment. The second part included questions about quality of service provided to guests in the hotel in general. The third part measured customer satisfaction with their experience in the hotel.

The fourth part, asked hotel guests about their behavioral intentions towards the hotel they visited and finally the last part addressed some demographic variables, information was gathered on customers' characteristics like gender, marital status, age and highest level of education. 
Service environment or physical environment was measured using eighteen items -that include ambient conditions and facility aesthetics- adopted from (Wu \& Liang, 2009; Kim \& Moon, 2009; Hooper et al., 2013). Service quality was measured using twenty four-item scale measuring tangibles, responsiveness, reliability, assurance and empathy adopted from Parasuraman et al. (1985, 1988, 1991) SERVQUAL model. Customer satisfaction was measured using eight-item scale adopted from (Oliver, 1997; Lee et al., 2000; Ryu et al., 2008). Behavioral intention, on the other hand, was measured using ten-item scale adopted from relevant studies (Bitner, 1992; Zeithaml et al. 1996; Park et al. 2005; Jani \& Han 2011). All scales were measured through 7 point Likert type scale.

\section{Results}

Data collected mirror that the total mean score of Servicescape is a high mean score of 5.272 (SD, 1.196) led to better customer behavioral intentions 4.920 (SD, 1.573). As shown in Table (1), the mean score for the scales have high mean scores more than the midpoint of the scale (4).

First, a confirmatory factor analysis was conducted by using the covariance matrix to evaluate each construct's measures. The results showed that all items loaded highly on their respective factor. All critical ratio values exceeded the minimum guideline of 1.96 , with all values significant at the 0.001 levels.

The second-order factor model of Servicescape, which contains the sub constructs of room service environment (RSE) and public space enviroment (PSSE) was compared with a first-order factor model in which the eighteen items were reflective of one latent variable, the CFA results showed that the first-order model provided a better fit to the data than the second-order model. Moreover, the standard errors for the items ranged from 0.115 to 0.178 and all the item loadings were more than twice their standard error. Factor loadings for the constructs were significant ( $t$ values ranged from 3.77 to 16.78), indicating excellent convergent validity of the items to each factor. Construct reliability was high, as indicated by composite alpha (ranged from 0.618 to 0.971), composite reliability values were all greater than the recommended value of more than 0.60 (Bagozzi \& YI, 1988).

Moreover, the results indicate that all Cronbach's alpha values for all the constructs ranged from 0.845 to 0.974 demonstrating that the instrument is reliable. Goodness of fit for the measurement model was found to be good. In sum, the measurement model is supported, where all the resulting measurement model statistics suggested a good fit to the data (see Table 1).

Table 1 Constructs Means, Standard Deviations, and Confirmatory Factor Analysis Results

\begin{tabular}{|l|c|c|c|c|c|}
\hline \multicolumn{1}{|c|}{ Construct } & Mean & SD & C.R. & AVE & $\begin{array}{c}\text { Cronbach's } \\
\text { Alpha }\end{array}$ \\
\hline RSE & 5.353 & 1.200 & 0.929 & 0.504 & 0.929 \\
\hline PSSE & 5.190 & 1.308 & 0.934 & 0.525 & 0.940 \\
\cline { 6 - 7 }
\end{tabular}




\begin{tabular}{|l|l|l|l|l|l|}
\hline Servicescape & 5.272 & 1.196 & 0.965 & 0.514 & 0.961 \\
\hline Service Quality & 5.408 & 1.118 & 0.618 & 0.596 & 0.845 \\
\hline Customer Satisfaction & 4.957 & 1.416 & 0.951 & 0.643 & 0.963 \\
\hline Behavioral Intentions & 4.920 & 1.573 & 0.971 & 0.773 & 0.974 \\
\hline
\end{tabular}

Table 2 compares the Inter-Construct Correlations and the Square Root of AVE for all constructs. The average variance extracted (AVE) values were well above the suggested .50 threshold (Fornell \& Larcker, 1981). To assess divergent validity, the square root of the AVE of each construct was compared with the correlation estimates between constructs, the square root of the AVE for each construct was higher than the correlation estimate between that construct and all other constructs (Hair et al., 2010), and this criterion is met for all possible construct pairs. Consequently, all the research constructs in this study are considered reliable (see Table 2).

Table 2 Inter-Construct Correlations and the Square Root of AVE

\begin{tabular}{|l|c|c|c|c|}
\hline \multicolumn{1}{|c|}{ Variables } & $\mathbf{1}$ & $\mathbf{2}$ & $\mathbf{3}$ & $\mathbf{4}$ \\
\hline 1.Servicescape & $\mathbf{. 7 1 7}$ & & & \\
\hline 2.Service Quality & .507 & $\mathbf{. 7 7 2}$ & & \\
\hline 3.Customer Satisfaction & .503 & .738 & $\mathbf{. 8 0 1}$ & \\
\hline 4. Behavioral Intentions & .459 & .764 & .621 & $\mathbf{. 8 7 9}$ \\
\hline
\end{tabular}

** Correlation is statistically significant with $p<0.01$. Diagonal

entries (in bold) are the square root of AVE; sub-diagonal entries are the latent construct inter-correlations.

\section{Structural Model}

The purpose of this part is to empirically examine and test the hypotheses of relationships between the study variables using structural equation modeling (SEM). In the current study, the proposed structural model is composed of four major latent constructs, of which one is exogenous (servicescape) and three are endogenous (service quality, customer satisfaction and behavior intention). Figure 2 presents the structural model and the proposed relationships among the constructs. The study tested the proposed model by estimating the standardized path coefficients for the hypothesized relationships. The results indicated that the modified structural model yielded a good fit to the data: $\left(\mathrm{GFI}=.995, \mathrm{CFI}=.998, \mathrm{TLI}=.991, \mathrm{RMSEA}=0.078, \chi^{2} / d f=2.223\right)$.

The fit indices indicated that the modified structural model fit the data well, supporting to a large extent the basic theoretical model of the study. Thus, it could be argued that the servicesape dimensions have both direct and indirect effects on service quality, customer satisfaction and customer behavioral intentions (see Figure 2).

The analysis followed Anderson and Gerbing's (1988) two-step modeling approach to establish the measurement model, and then proceeded to the structural equation model (McDonald \& Ringo, 2002). The primary findings supported the basic theoretical model of the study to a large extent, where the basic model has been modified. The results suggested that the path between 
service quality and behavior intention should be deleted. After deleting that insignificant path, the fit of the modified model was compared with the fit of the basic theoretical model which included the path between service quality and behavior intention. The chi-square difference test $\left(\Delta \square^{\square}\right)$, with degrees of freedom equal to the difference in degrees of freedom between the models, is used to evaluate alternative nested models (Kline, 2005). The $\square^{\square}$ difference test showed that the basic structural model had not a significant good fit to the data in comparison with the modified model. After testing the structural equation, it was observed that the research basic model does not have a desirable fitness with data. The value of RMSEA fit index indicated bad fitness of the hypothesized structural model, and nearly all the fit indices did not fully meet the acceptance criteria for the proposed model and finally the proposed model was rejected and modified by deleting the bath between service quality and behavior intention.

A new model named as "modified model" was designed to omit the insignificant path and the weak relationship between (SQ) and (BI) from the initial model (see Figure 2). Falk and Miller (1992) suggested that the $R^{2}$ values above 0.10 are substantial. The $R^{2}$ values for all dependent constructs are above the recommended levels. According to Kline (2005), it is necessary to respecify the model and evaluate the fit of the revised model to the same data. Therefore, a revised submodel was submitted, in which the researcher tested the fit of a model created by eliminating the weak significant path from the initial model, the path linking the service quality and behavior intention was not significant $(\mathrm{p}=0.135)$, therefore, this path was omitted from the model; after this omission, all of the model's fitness indicators were improved. Structural analysis of the "modified model" revealed that the alternative revised model provided a significant good fit to the data better than the hypothesized structural model (see Figure 2).

According to AVE values, this criteria was fully satisfied because the AVE values separately found more than the shared variance values. So in summary, the Modified Model was found internally reliable, constructs were reliable and had convergent validity and discriminant validity, moreover all fit indices for modified model also confirmed the Fitness of this model. 


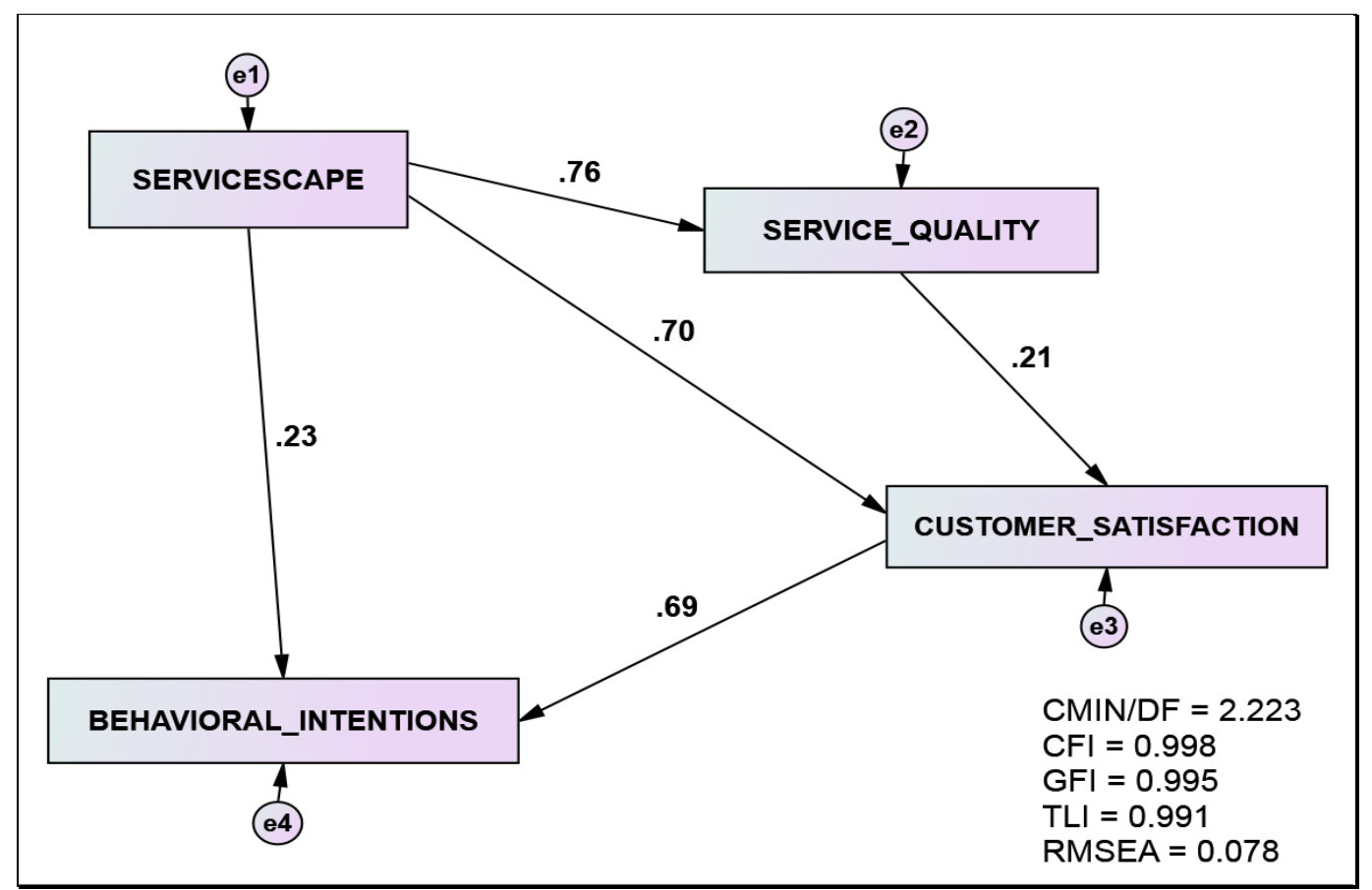

Figure 2: Servicescape, service quality, customer satisfaction and behavioral intentions

Based on the above discussion, it can be summarized that the proposed model fits the data well and also as a result, it is capable to explain the hypotheses. Two sets of relationships will be examined: direct and mediating relationships. The results of testing the hypothesized direct relationships are presented first.

\section{Hypotheses Testing Direct Relationships}

Table 3 presents the results of testing the hypothesized direct relationships. It also includes the standardized path coefficients, $t$-values, and the corresponding significance levels. To test specific construct relationships, the study examined standardized parameter estimates for all construct pairs. The results revealed that the hypothesized relationship between service quality and customer behavioral intentions was not statistically significant. The study expected servicescape to have direct effect on customer behavioral intentions.

The study proposed that servicescape and service quality affects customer satisfaction and customer behavioral intentions; that is, positive customer satisfaction is considered as a mediator between servicescape, service quality and behavioral Intentions. In support of this construal, results identify these links and, in sum, all hypothesized relationships were statistically significant ( $\beta$ $=.261$ to $\beta=.824$ ). The study found all the paths are significant paths except the path between service quality and customer behavioral intentions $(\beta=.074, \mathrm{t}$ $=1.495, \mathrm{p}=0.135)$. Hence, hypotheses are supported, except hypothesis 5 was not supported and rejected (see Table 3 ).

Table 3: Hypotheses Test Results for the Proposed Structural Model 


\begin{tabular}{|c|l|c|c|c|}
\hline Hypotheses & \multicolumn{1}{|c|}{ Hypothesized Relationship } & $\begin{array}{c}\text { Standardized } \\
\text { Coefficient }\end{array}$ & $\boldsymbol{t}$-value & Result \\
\hline H1 & Servicescape $\rightarrow$ Behavioral Intentions & 0.308 & $3.916^{* * * *}$ & Supported \\
\hline $\boldsymbol{H 2}$ & Servicescape $\rightarrow$ Customer Satisfaction & 0.824 & $12.705^{* * * *}$ & Supported \\
\hline $\boldsymbol{H 3}$ & Servicescape $\rightarrow$ Service Quality & 0.713 & $16.781^{* * *}$ & Supported \\
\hline $\boldsymbol{H 4}$ & Service Quality $\rightarrow$ Customer Satisfaction & 0.261 & $3.766^{* * * *}$ & Supported \\
\hline $\boldsymbol{H 5}$ & Service Quality $\rightarrow$ Behavioral Intentions & 0.074 & 1.495 & Not Supported \\
\hline H6 & $\begin{array}{l}\text { Customer Satisfaction } \rightarrow \text { Behavioral } \\
\text { Intentions }\end{array}$ & 0.765 & $11.525^{* * *}$ & Supported \\
\hline
\end{tabular}

$* * * p<0.001, * * p<0.01,{ }^{*} p<0.05,{ }^{m . s} . p<0.1$

To test for mediation, the Sobel test with boot-strapped standard errors based on 1000 resampling was conducted. The results of Sobel test are presented in Table 4. The results were consistent with the results of the basic hypotheses. The study predicted significant positive relationships between servicescape, and behavioral intentions mediated by service quality and customer satisfaction. The mediating effects based on the effectiveness of servicescape requirements were found to be significant and assure higher levels of customer satisfaction, that higher customers' satisfaction is due to their perception of service quality and the fulfillment of servicescape requirements leads to better behavioral intentions. (See Table 4).

Table 4: Sobel Test Results

\begin{tabular}{|l|c|c|c|}
\hline \multicolumn{1}{|c|}{ Indirect Effects } & $\begin{array}{c}\text { Sobel } \\
\text { Test }\end{array}$ & $\begin{array}{c}\text { Standard } \\
\text { Error }\end{array}$ & $\begin{array}{c}\text { Mediating } \\
\text { Effect }\end{array}$ \\
\hline$S C A P E \rightarrow S Q \rightarrow C S$ & 3.692 & $0.050 * * *$ & Partial \\
\hline$S C A P E \rightarrow C S \rightarrow B I$ & 8.554 & $0.073 * * *$ & Partial \\
\hline$S Q \rightarrow C S \rightarrow B I$ & 3.559 & $0.055 * * *$ & Partial \\
\hline
\end{tabular}

$* * * p<0.001, * * p<0.01,{ }^{*} p<0.05,{ }^{m . s .} . p<0.1$

As shown in Table 4, the results confirm that service quality had a mediating effect on the relationship between servicescape and customer satisfaction (Sobel test $=3.692, p<0.001$ ). The results also confirm that customer satisfaction had a mediating effect on the relationship between servicescape and behavioral intentions (Sobel test $=8.554, p<0.001$ ). Furthermore, the findings in Table 4 confirm that customer satisfaction had a mediating effect on the relationship between service quality and behavioral intentions (Sobel test $=3.559, p<0.001$ ).

\section{Discussion, Conclusions and limitations}


As revealed in the results section, the empirical study found that the hypothesized positive relationship between servicescape and behavioral intentions is supported, which confirms with previous researches findings (Donovan and Rossiter, 1982; Wakefield and Blodgett, 1996; Chang, 2000; Ryu and Jang, 2007; Liu and Jang, 2009; Ibrahim 2009; Ryu and Han, 2010; Change 2016). The second hypothesized relationship between servicescape and customer satisfaction was found to be also supported, this finding agrees with previous researches findings (Bitner 1992; Wakefield and Blodgett (1994, 1996, 1999); Lucas 2003; Ryu and Han 2010; Lam, et al. 2011; Jana and Chatterjee 2014). The results also showed that the third hypothesized positive relation between servicescape and service quality is found to be supported, which confirms with the results of (Hightower et al., 2002; Reimer and Kuehn 2005 and hooper and Coughlan 2013). Moreover, as suggested, service quality was found to influence customer satisfaction positively, this finding confirms with the work of plenty of researchers (Bitner, 1990; Cronin and Taylor, 1992; Oliver, 1981; Parasuraman et al. 1988; Ting 2004; Markovic and Jankovic. 2013; subashini 2016).

Interestingly, It was found that the fifth hypothesized relation between service quality and behavioral intentions was not supported, that is Quality of service offered to customers in luxury hotels does not influence their behavioral intentions, which contradicts with previous researchers finding (Barksy and Labagh 1992; Gonzales et al. 2007; Jang and Namkung 2008; Salazar et al. 2010; Gounaris, et al. 2010; Amin and Nasharuddin 2013). Finally, The last hypothesized relationship between customer satisfaction and behavioral intentions is found to be supported, which coincide with the work of (Rust and Williams, 1994; Getty and Thompson 1995; Oh 2000; Lucas 2003; Han and Ryu 2007; Han and Back 2008; Han et al. 2009; Lee et al. 2010; Chen and Chen, 2010; Lam et al. 2011; Jani and Han 2013).

The study has a number of limitations. The selected sample is a convenience sample, and in spite of the advantages of selecting such sampling technique, this can cause some measurement problems. The study was limited to only three luxury hotels in one region. Future research should include different types and brands of hotels.

\section{References}

Amin, M. and Nasharuddin, S. Z. (2013). Hospital service quality and its effects on patient satisfaction and behavioral intention. Clinical Governance: An International Journal, 18(3), 238 - 254.

Anderson, J. G. and Gerbing, D. W. (1988). Structural modeling in practice: A review and recommended two-step approach. Psychological Bulletin, 103(3), 411-423.

Bagozzi, R. P. and Yi, Y. (1988). On the evaluation of structural equation models. Journal of the Academy of Marketing Science, 16(1), pp. 74-94.

Chang, J. C. (2016). The impact of servicescape on quality perception and customers' behavioral intentions. Advances in Management and Applied Economics, 6 (4), 67-86. 
Chen, C. F. and Chen, F. S. (2010). Experience quality, perceived value, satisfaction and behavioral intentions for heritage tourists. Journal of Tourism Management, 31(1), 29-35.

Dedeoğlu, B. B., Küçükergin, K. G. and Balıkçıŏlu, S. (2015). Understanding the relationships of servicescape, value, image, pleasure, and behavioral intentions among hotel customers. Journal of Travel \& Tourism Marketing, 32(1), 42-61.

Dong, P. and Siu, N. Y. M. (2013). Servicescape elements, customer predispositions and service experience: The case of theme park visitors. Journal of Tourism Management, 36, (3), 541-551.

Falk, R. F. and Miller, N. B. (1992). A Primer for Soft Modelling. Akron: Ohio University of Akron Press.

Fornell, C. and Larcker, D. F. (1981). Evaluating structural equation models with unobservable variables and measurement error. Journal of Marketing Research, 18(3), 39-50.

Gounaris, S., Dimitriadis, S. and Stathakopoulos, V. (2010). An examination of the effects of service quality and satisfaction on customers' behavioral intentions in e-shopping. Journal of Services Marketing, 24 (2), 142-156.

Hair, J. F., Black, W. C., Babin, B. J. and Anderson, R. E. (2010). Multivariate data analysis: A global perspective (7ed.). London: Pearson.

Han, H. and Back, K. (2008). Relationships among image congruence, consumption emotions, and customer loyalty in the lodging industry. Journal of Hospitality \& Tourism Research, 32(4), 467-490

Han, H. and Ryu, K. (2009). The roles of the physical environment, price perception, and customer satisfaction in determining customer loyalty in the restaurant industry. Journal of Hospitality \& Tourism Research, 3(4), 487-510.

Harris, L. C. and Ezeh, C. (2008). Servicescape and loyalty intentions: an empirical investigation. European Journal of Marketing, 42 (3/4), 390-422.

Heung, V. C. and Gu, T. (2012). Influence of restaurant atmospherics on patron satisfaction and behavioral intentions. International Journal of Hospitality Management, 31(4), 1167-1177.

Hooper, D., Coughlan, J. Mullen .M. R. (2013). The servicescape as an antecedent to service quality and behavioral intentions. Journal of Services Marketing. 27 (4), 271-280.

Hyun, S. S. and Kang, J. (2014). A better investment in luxury restaurants: environmental ornon-environmental cues?. International Journal of Hospitality Management, 39 (7), 57-70.

Ibrahim, Y. (2009). The effects of the servicescape on consumers' behavioral intentions in the UK coffee shop market. Egyptian Journal of Tourism Studies, $8(2), 45-75$. 
Jana, A. and Chatterjee, R. (2014). The effect of servicescape of casual restaurants on youths dining experience. International Journal on Customer Relations, 2(2), 37-44.

Jang, S. and Namkung, Y. (2009). Perceived quality, emotions, and behavioral intentions: Application of an extended Mehrabian-Russell model to restaurants. Journal of Business Research, 62 (3), 451-460.

Jang, S. and Namkung, Y. (2008). Are highly satisfied restaurant customers really different? A quality perception perspective. International Journal of Contemporary Hospitality Management, 20(2), 142-155,

Jani, D. and Han, H. (2013). Personality, social comparison, consumption emotions, satisfaction, and behavioral intentions. International Journal of Contemporary Hospitality Management, 25(7), 970-993.

Jani, D. and Han, H. (2011). Investigating the key factors affecting behavioral intentions: evidence from a full-service restaurant setting. International Journal of Contemporary Hospitality Management, 23(7), 1000-1018.

Kim, W. G. and Moon, Y. J. (2009). Customers' cognitive, emotional, and actionable response to the servicescape: a test of the moderating effect of the restaurant type. International Journal of Hospitality Management, 28(1), 144156.

Kline, R. B. (2005). Principles and practice of structural equation modeling. ( $2^{\text {nd }}$ ed.). New York, NY: The Guilford Press.

Ladhari, R., Brun, I. and Morales, M. (2008). Determinants of dining satisfaction and post-dining behavioral intentions. International Journal of Hospitality Management, 27(4), 568-573.

Lam, L. W., Chan, K. W., Fong, D. and Lo, F. (2011). Does the look matter? The impact of casino servicescape on gaming customer satisfaction, intention to revisit, and desire to stay. International Journal of Hospitality Management, 30(12), 558-567.

Lee, H., Lee, Y. and Yoo, D. (2010). The determinants of perceived service quality and its relationship with satisfaction. Journal of Services Marketing, 14(3), 217-231.

Lee, S. Y. (2014). Effects of servicescape on perceived service quality, satisfaction and behavioral outcomes in public service facilities. Journal of Asian architecture and building engineering, 13(1), 125.

Lee, T. J. and Nam, J. H. (2011). Foreign travelers' satisfaction with traditional Korean restaurants. International Journal of Hospitality Management, 30 (4), 982-989.

Lin, I. Y., and Mattila, A. S. (2010). Restaurant servicescape, service encounter, and perceived congruency on customers' emotions and satisfaction. Journal of Hospitality Marketing \& Management, 19(8), 819-841. 
Lin, I. Y. (2004). Evaluating Servicescape: the effect of cognition and emotion. International Journal of Hospitality Management, 23(2), 63-178.

Liu, Y., and Jang, S. (2009). The effects of dining atmospherics: an extended Mehrabian-Russell model. International Journal of Hospitality Management, 28(4), 494-503.

Mari, M., and Poggesi, S. (2013). Servicescape cues and customer behavior: a systematic literature review and research agenda. The Service Industries Journal, 33(2), 171-199.

Markovic, S. and Jankovic, S. R. (2013). Exploring the relationship between service quality and customer satisfaction in Croatian hotel industry. Tourism and Hospitality Management, 19(2), 149-164.

McDonald, R. P. and Ringo, H. M. H. (2002). Principles and practice in reporting structural equation analyses. Psychological Methods, 7(1), 64-82.

Morrison, M., Gan, Dubelaar, C. and Oppewal, H (2011). In store music and aroma influences on shopper behavior and satisfaction. Journal of Business Research, 64(6), 558-564.

Ryu, K. and Han, H. (2010). Influence of the quality of food, service, and physical environment on customer satisfaction in quick-casual restaurants: moderating role of perceived price. Journal of Hospitality \& Tourism Research, 34 (3), 310-329.

Ryu, K. and Jang, S. (2008). DINESCAPE: a scale for customers' perception of dining environments. Journal of Foodservice Business Research, 11(1), 222.

Salazar, A., Costa, J. and Rita, P. (2010). A service quality evaluation scale for the hospitality sector: Dimensions, attributes and behavioral intentions", Worldwide Hospitality and Tourism Themes, 2 (4), 383-397.

Shashikala R. and Suresh A. M (2013). Building consumer loyalty through servicescape in shopping malls. Journal of Business and Management, 10(6), 11-17.

Subashini, R. (2016). A review of service quality and customer satisfaction in banking services: global scenario. Journal of Internet Banking and Commerce, 21(5), 1-9.

Voon, B. H., Jager, J., Chitra, K., Kueh, K. and Jussem, P.M. (2013). Human service matters: a cross-national study in restaurant industry. Asian Journal of Business Research, 3(2), 1-11.

Wang, C. Y. and Mattila, A. S. (2013). The impact of servicescape cues on consumer pre purchase authenticity assessment and patronage intentions to ethnic restaurants. Journal of Hospitality \& Tourism Research. 39(3), 346-372.

Wu, C. H. and Liang, R. D. (2009). Effect of experiential value on customer satisfaction with service encounters in luxury-hotel restaurants. International Journal of Hospitality Management. 28(4), 586-593. 


\section{تأثير بيئة وجودة الخدمة على رضاء العملاء ونواياهم السلوكية في الفنادق}

الملخص العربي

الهدف من هذه الدر اسة هو اقتراح نموذج منكامل لإختبار نأثثير بيئة وجودة الخدمة على رضاء العملاء

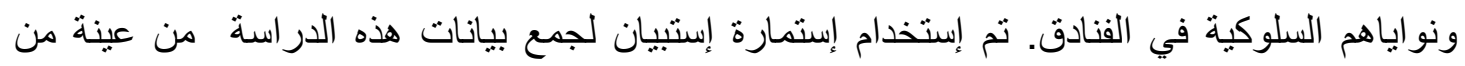

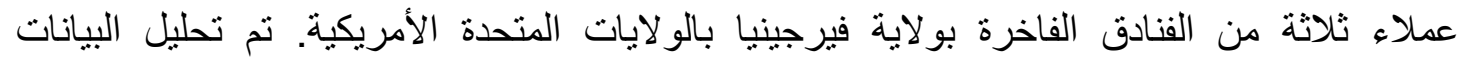

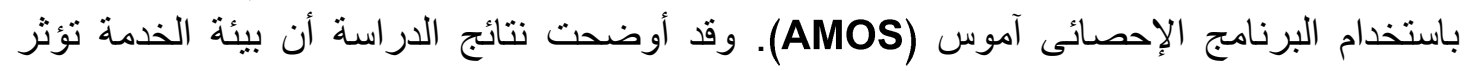

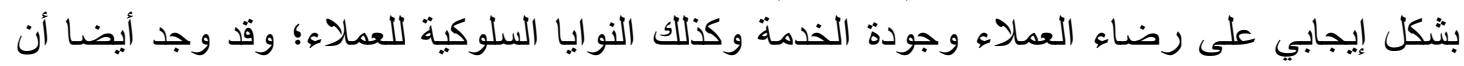

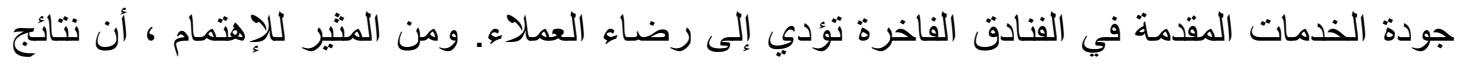

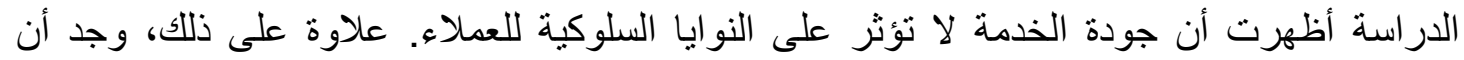

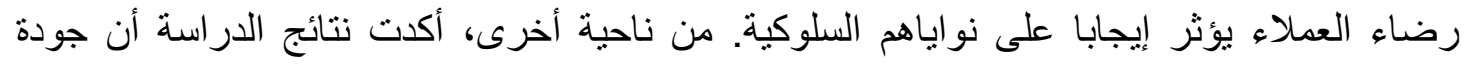

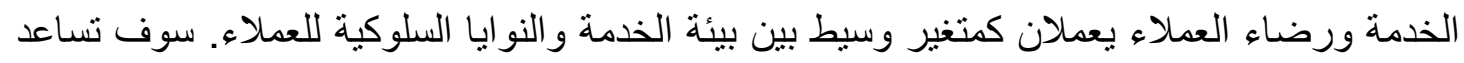

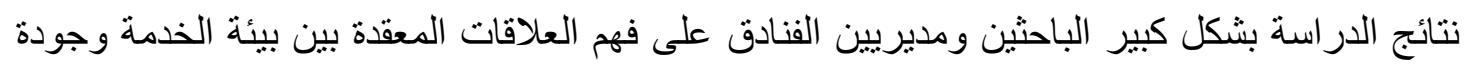

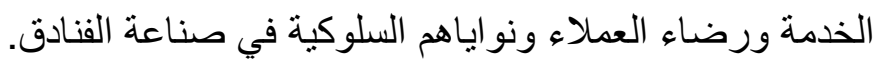

الكلمات المفتاحية: بيئة الخدمة ، جودة الخدمة ، رضاء العملاء ، النوايا السلوكية. 